\title{
コンクリートの耐凍性に対する北海道産骨材の 影響について
}

正会員服部隆*

1. 序 コンクリートの凍害が使用骨材により受ける 影響を有らか反するためと、粗、細骨材 24 及び 22 種 で条件を同じそしたコンクリート及びモルタル供試体を 作り耐凍害性の比較を行つた。此の実験により主な北海 道産骨材相互の耐凍害性を判定する資料が得られた。寒 冷地泛於てコンクリートの柎久性上に凍害は大きな影響 をあた党て招り、建築物の被害が重要視される場同もあ る。従来種々の研究がコンクリートの耐凍害性について 行われて来ているが、骨材を主としたのは少く、且つ各 々の資料の比較が困難であつた。耐棟害性について余り 考慮されない場合の、一般に茟築て用いられる調合での プレインコンクリートが凍害を受けた時にその使用する 骨材の良否により被害任差を生ずるかを知る為に、各骨 材につき同一条件で涷結融解試験を行つた。これとより 主に北海道内で使用されている骨材の耐凍害性上より見 た品質の一端を明らがし、骨材の物理的な性状とコン クリートの倲害との関係について考察した。

\section{2. 実験計画}

\section{1 使用材料}

a ）セメント：普通ポルトランドセメントで日本セメ ント上磯工場製アサノセメントを使用した。その強度試 験結果を第 1 表に示す。

第 1 表 セメント強度

\begin{tabular}{|c|c|c|c|c|c|c|c|c|}
\hline 名 & 称 & ロー & \multicolumn{3}{|c|}{ 曲げ強さ $\mathrm{kg} / \mathrm{cm}^{2}$} & \multicolumn{3}{|c|}{ 圧縮強さ $\mathrm{kg} / \mathrm{cm}^{2}$} \\
\hline \multirow{2}{*}{\multicolumn{2}{|c|}{$\begin{array}{l}\text { アサアプッーポ } \\
\text { ルトランドセメ } \\
\text { ント }\end{array}$}} & \multirow{2}{*}{193} & & 7日 & & 3日 & 7日 & 28日 \\
\hline & & & & 42.3 & & & 196 & \\
\hline
\end{tabular}

b ) 骨材 : 試料の選択は北海道内主要都市に供給され る主な骨材を試験設備の限度内で広範囲に試験と供する 様にした。

1）粗骨材 道内主要都市に供給される主な骨材とし て砂利を 21 種、碎石 2 種を選び、且つ比較のためと本 州産の砂利 1 種を試験飞供した。産地及び各種試験の結 果を第 5 表江示す。試料はコンクリート供試体作成上条 件を揃党比較を容易にする為飞、25 mm $20 \mathrm{~mm} 15 \mathrm{~mm}$ $10 \mathrm{~mm} 5 \mathrm{~mm}$ のフルイで水洗いしつつフルイ分けた後 に一定粒度に調整した。その粒度は第 2 表に示す。

2) 細骨材 道内の主な細骨材を 22 種試験供し た。座地及び各種試験の結果を第 6 表に示す。粒度調整

* 北海道大学工学部, 助手
第 2 表 粗骨材試料粒度

\begin{tabular}{c|c|c|c|c}
\hline 精 径 $\mathrm{mm}$ & $5 \sim 10$ & $10 \sim 15$ & $15 \sim 20$ & $20 \sim 25$ \\
\hline 重量百分率 $(\%)$ & 20 & 35 & 35 & 10 \\
\hline
\end{tabular}

は $5 \mathrm{~mm}$ フルイ全量通過分を使用する事に止めた。

2.1 供試験の作成

1）コンクリートの調合：粒度を調整した各粗骨材を 涌沸産の細骨材を用いて同一の水セメント比、セメント 使用量、砂率を条件として JASS 5 「鉄筋コンクリート 工事」の標準調合表に依つて試し練を行い決めた。水セ メント比としては 寒冷地の耐凍害性を目的とした限界 60\%をとるのが原則であろうが、実際建築に多く用い られている特酎凍害性を考えないコンクリートを基と して $65 \%$ とした。セメント量は $293 \mathrm{~kg} / \mathrm{cm}^{2}$ とし、砂 率は $37 \%$ 、スランプは 17〜18 cm を目標として第 3 表 の調合を定めた。但し碚石も同一調合とし、スランプを 測定した。

第 3 表 供試体の調合

\begin{tabular}{|c|c|c|c|c|c|}
\hline \multirow{2}{*}{$\mathrm{W} / \mathrm{C} \%$} & \multirow{2}{*}{$\begin{array}{c}\text { スランプ } \\
\mathrm{cm}\end{array}$} & \multirow{2}{*}{$\begin{array}{c}\text { 有効水量 } \\
\qquad / / \mathrm{m}^{3}\end{array}$} & \multicolumn{3}{|c|}{ 絶対容積比 $\mathrm{t} / \mathrm{m}^{3}$} \\
\hline & & & セメント & 砂 & 砂利 \\
\hline 65 & 18 & 190 & 93 & 261 & 446 \\
\hline
\end{tabular}

2) モルタルの調合：各細骨材の粒度調整は実際の使 用上より見て不合理であり、試料の量よりの困離な点も あり同一にする事が出来得なかつた。従つてモルタルの 調合を決定する当つて次の事が考えられる。即ち

イ）フロー值一定で調合する法、従つてセメント使用 量が変化ずる。

ロ）調合及び水セメント比を一定にしてフロー值を測 定するにとどめる法。

との二つが考光られるが、本実験では簡単にする為に後 者（口）の方法をとつた。しかし強度の面では、粒度の 影響を受け、更に耐凍害性の比較の上でも単純には比較 する事が出来ないが、イ）の場合のフロ一值一定でセメ ント使用量を変えた方法より、整理が簡単であると考え る。故に水セメント比を一定として $65 \%$ に定め絶対容 積比で 1:4 のモルタルとした。

3）コンクリート供試体の製作と養生

涷結融解試験用のコンクリート供試験の寸法は $7.5 \times$ $7.5 \times 40 \mathrm{~cm}$ として型枠には 2 周に打込み突棒で 18 回 乫いた。㕛強度試験用に一部はシリンダーを作製した。 
供試体は、打込後 24 時間 $20^{\circ} \mathrm{C}$ 保温箱に養生した後脱 型した。養生は $20^{\circ} \mathrm{C} \pm 3^{\circ} \mathrm{C}$ の水中で材令 2 週まで養生 した。凍結融解を同時に開始する関係上（作成日が型模 の関係で5日斿たつて行われ、又、モルタル供試体と 同時に行うため) 供試体はポリエチレンチューブで包装 密封の上、気中で倲結保存した。な稆コンクリート作成 にあたり骨材の形状の差によるスランプの差を測定し第 5 表に示した。又供試体は 1 種につき 3 ケを標準とし た。

4）モルタル供試体の製作と養生 凍結融解試験用の モルタル供誌体の寸法は $4 \times 4 \times 40 \mathrm{~cm}$ で型枠にセメン トの強さ試験に準じて打込み、脱型及び養生はコンクリ 一ト供試体に準じた。フロー值は第 6 表に示す。供試体 は 1 種につき 4 ケを標準とした。

\section{3 強度試験}

凍結融解開始前の供試体の強度を骨材別にみる為に、 コンタリート並びにモルタルに就き行つた。

1) 粗骨材 各々 $15 \phi \times 30 \mathrm{~cm}$ のシリンダー 3 ケを作 製する予定であつたが、試料骨材の不足から数種のみし か試験する事が出来なかつた。結果は此の報告には省略 する。

2) 細骨材 各々 $4 \times 4 \times 16 \mathrm{~cm}$ の供試体 3 ケずつ作 成した。此の第 7 図、第 8 図に示す。

\section{4 凍結融解試験}

凍結融解法は ASTM を参考として 1 日 1 サイクルの

第 5 表 粗骨材、コンクリート供試体の性状

\begin{tabular}{|c|c|c|c|c|c|c|c|c|c|}
\hline 地 & 産地 & 纪号 & 積 & 此重 & 吸水 & 安定性 & 形態 & $\begin{array}{l}\text { スラ } \\
\text { ンプ }\end{array}$ & 動弹性係 \\
\hline \multirow{3}{*}{ 石 } & 当別川 & $\mathrm{Tb}$ & 川 & 2.60 & 2.24 & 5.09 & 稍偏平 & 20.0 & $3.54 \times 10$ \\
\hline & 広 島 & $\mathrm{Hi}$ & 山 & & 1.21 & 2.62 & 丸 味 & 21.0 & \\
\hline & 豊平川 & Ty & 川 & 50 & .40 & 3.59 & 粗 面 & 20.0 & $3.08 "$ \\
\hline \multirow[t]{2}{*}{ 狩 } & 豊 平 & Ts & 础 & & 2.07 & $\ldots$ & 稜 角 & 18.0 & $3.52 "$ \\
\hline & 漁 川 & Is & III & & .55 & - & 粗 面 & 21.0 & $3.10 "$ \\
\hline \multirow{3}{*}{$\begin{array}{l}\text { 空 } \\
\text { 知 }\end{array}$} & 砂 川 & Su & 川 & & 2.10 & 3.06 & 丸 味 & 20.0 & $3.02 "$ \\
\hline & 滝 川 & $\mathrm{Ti}$ & $川$ & 2.60 & 1.60 & - & & 20.0 & $3.30 "$ \\
\hline & 富良野 & $\mathbf{F r}$ & 川 & 2.68 & .60 & 5.31 & 稍稜角 & 20.5 & $3.32 "$ \\
\hline \multirow[t]{3}{*}{ 上 } & 石狩川 & Ik & 川 & & .00 & - & 丸 味 & 20.0 & $3.40 "$ \\
\hline & 此 布 & $\mathrm{Hp}$ & III & 2.55 & .15 & - & & 21.0 & $3.39 "$ \\
\hline & 辺別川 & $\mathrm{Hn}$ & 川 & & .09 & 4.42 & 稍稜角 & 21.0 & $3.43 "$ \\
\hline \multirow{3}{*}{$\begin{array}{l}\text { 留 } \\
\text { 檠 } \\
\text { 壏 }\end{array}$} & 遠別川 & En & 川 & & & - & 丸 味 & 21.2 & $1 "$ \\
\hline & 羽晎川 & $\mathrm{Hb}$ & 川 & & 0 & 2.00 & " & 20.5 & $3.53 \%$ \\
\hline & 名寄川 & $\mathrm{Na}$ & 川 & & & & 稍偏平 & 20.0 & $3.33 "$ \\
\hline 因走 & 常呂川 & Tk & 川 & 2.63 & .56 & - & 稍稜角 & 20.0 & $3.22 \%$ \\
\hline 千勝 & 札内川 & $\mathrm{Sa}$ & 川 & & & 2.94 & 丸 味 & 21.0 & $2.36 "$ \\
\hline \multirow{3}{*}{$\begin{array}{c}\text { 景 } \\
\text { 嵒 } \\
\text { 振 }\end{array}$} & & $\mathrm{Si}$ & 海 & & & .98 & 丸 味 & 0.0 & 3.43 " \\
\hline & 珷 川 & $\mathrm{Ma}$ & 川 & & .05 & 3.55 & 稍稜角 & 19.3 & $3.51 "$ \\
\hline & 室 蘭 & $\mathbf{M r}$ & 砕 & & 3.43 & & 丸 味 & 19.0 & 2.74 \\
\hline \multirow{3}{*}{$\begin{array}{l}\text { 後 } \\
\text { 志 }\end{array}$} & 尻別川 & & 川 & & & 2.16 & & 18.0 & $3.11 "$ \\
\hline & 古 平 & Fb & 海 & & & - & 丸 味 & 21.5 & 3.81 " \\
\hline & 小樽 & Ot & 砕 & & 2.74 & 6.70 & 偏 平 & 10.7 & 3.26 " \\
\hline & 扢し泊 & Os & 海 & 2.41 & 2.10 & - & 多角有孔 & 19.0 & 2.74 \\
\hline 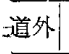 & 相模川 & $\mathrm{Sg}$ & 川 & & & 5.34 & 丸 味 & 20.0 & $3.43 "$ \\
\hline
\end{tabular}

水市凍結融解を行つた。

1）試験装置、凍結用塩化カルシューム溶液槽は $90 \times$ $90 \times 60 \mathrm{~cm}$ のb 2 ケを低温室内で一馬力の冷倲機で泠 却して使用し、融解槽は、 $180 \times 180 \times 60 \mathrm{~cm}$ の寸法のも のに冷凍機の冷却水を使用した。

2）凍結融解方法：供試体は麻繩を十文字に巻きつけ てコンクリートは $8 \times 8 \times 60 \mathrm{~cm}$ のゴム袋へ1ケを、モ ルタルは $9 \times 9 \times 60 \mathrm{~cm}$ のゴム袋へ 4 ケを入れた。水は $0.3 \sim 0.4 l$ 注ぎ供試体が薄い部分で $2 \mathrm{~mm}$ 厚い部分で 約 $15 \mathrm{~mm}$ 水で括括われる様にして第 4 表に示す凍結融 解を行つた。

第 4 表 凍結融解（水中）

\begin{tabular}{|c|c|c|c|}
\hline \multicolumn{2}{|c|}{ 凍結（塩カル溶液槽） } & 融 & （水槽） \\
\hline 温度 ${ }^{\circ} \mathrm{C}$ & 時間 $h$ & 温度 ${ }^{\circ} \mathrm{C}$ & 時間 $h$ \\
\hline$-12 \sim-18$ & $18 \sim 20$ & $+8 \sim+15$ & $4 \sim 6$ \\
\hline
\end{tabular}

3）動弾性係数の測定：コンクリート、モルタル共に 凍結融解、5 回毎にゴム袋より出して ASTM，C 215$55 \mathrm{~T}$ に準じて撓み一次共振周波数を測定し、動弹性係数 の低下を求めた。凍融前の動弾性係数忹第 5，6 表に示 す。㕛低下の百分率を第 1 図〜第 6 図に示す。

4) 表面の観察 : 供試体表面に瑓結融解によつて生じ る変化を写真撮影によつて記録した。

5）粗骨材飞起因する点蝕：供試体表面で明らかて粗 骨材によつて生じたと見られる点蝕数を計测し、単位面

第 6表 細骨材、モルタル供試体の性状

\begin{tabular}{|c|c|c|c|c|c|c|c|c|c|}
\hline 地 & 産地 & 萴号 & 種 & 比重 & 吸水 & 安定性 & 形態 & フロー & 弾性係数 \\
\hline \multirow{3}{*}{ 石 } & 当別川 & $\mathrm{Tb}$ & 川 & 2.62 & 2.30 & 6.51 & 稍偏平 & 19.6 & $2.36 \times 10^{5}$ \\
\hline & 広 島 & $\mathrm{Hi}$ & 山 & 2.60 & 1.62 & 3.13 & 丸 味 & 22.2 & 2.58 \\
\hline & 豊平川 & Ty & 川 & 2.44 & 3.78 & 9.11 & 稜 角 & 21.2 & $2.10 "$ \\
\hline \multirow[t]{2}{*}{ 狩 } & 江 別 & $\mathrm{Eb}$ & 川 & 2.54 & 3.18 & - & 丸 味 & 17.5 & $1.68 "$ \\
\hline & 矢白場 & Ya & 山 & 2.60 & 2.70 & 6.93 & 稍稜角 & 12.4 & $2.11 "$ \\
\hline 空 & 砂 川 & Su & 川 & 2.48 & 2.20 & - & 丸 味 & 17.5 & 2.17 \\
\hline 知 & 滝 川 & $\mathrm{T} \mathbf{i}$ & 川 & 2.58 & 3.00 & - & 丸 味 & 21.8 & $2.41 "$ \\
\hline \multirow{3}{*}{$\begin{array}{l}\text { 上 } \\
\text { 川 }\end{array}$} & 狩川 & Ik & 川 & 2.58 & 60 & - & 稍稜角 & 13.5 & $2.09 "$ \\
\hline & 忠別川 & Th & 川 & 2.53 & 3.90 & - & " & 15.5 & $2.01 "$ \\
\hline & 辺別川 & $\mathrm{Hn}$ & 川 & 2.51 & 6.00 & 3.81 & $"$ & 13.8 & $1.96 "$ \\
\hline \multirow{3}{*}{$\begin{array}{l}\text { 留 } \\
\text { 笑 } \\
\text { 壏 }\end{array}$} & 遠別川 & En & 川 & 2.64 & 1.50 & - & 丸 味 & 22.1 & $2.59 "$ \\
\hline & 留 萠 & $\mathbf{R n}$ & 海 & 2.70 & 2.00 & - & 硝稜角 & 13.6 & $1.86 "$ \\
\hline & 名寄川 & $\mathrm{Na}$ & 川 & 2.58 & 1.55 & - & " & 18.9 & $2.42 "$ \\
\hline \multirow{3}{*}{$\begin{array}{l}\text { 網 } \\
\text { 走 }\end{array}$} & 下湧別 & $\mathrm{Ub}$ & 川 & 2.59 & 2.35 & 11.23 & 稍稜角 & 15.9 & $1.85 \mathrm{\prime \prime}$ \\
\hline & 無賀川 & Mk & 川 & 2.58 & 5.50 & - & " & 21.1 & $2.29 "$ \\
\hline & 根 室 & $\mathrm{Ne}$ & 海 & 2.66 & 1.09 & 8.06 & 棱 角 & 19.9 & $2.47 "$ \\
\hline 勝 & 十勝川 & To & 川 & 2.47 & 2.97 & 4.93 & 稍稯角 & 10.8 & 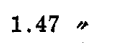 \\
\hline \multirow{3}{*}{ 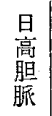 } & 静 内 & $\mathrm{Si}$ & 海 & 2.76 & 0.78 & 2.79 & 稍稜角 & 24.3 & $2.83 "$ \\
\hline & 鷲 別 & Wa & 海 & 2.71 & & 2.36 & " & 19.1 & $2.63 "$ \\
\hline & 涌＼cjkstart沸 & $Y_{n}$ & 海 & 2.76 & 1.32 & - & $"$ & 17.8 & $2.64 \Rightarrow$ \\
\hline & 古 平 & $\mathrm{Fb}$ & 海 & 2.63 & 1.58 & $\div$ & 丸 味 & 14.4 & 2.21 " \\
\hline & 大 森 & $\mathrm{Om}$ & 海。 & 2.82 & 0.55 & 2.98 & 棱 角 & 10.1 & $1.44 \%$ \\
\hline
\end{tabular}


積当りの点蝕数で表す代りに、共試体数について表わし 第 4 図一第 6 図に示した。供試体 1 本長手 4 面の面積は 約 $1200 \mathrm{~cm}^{2}$ である。但し隅角部等で動弾性係数測定時 取扱の衝撃による外的な原因で生じたと認められるるの 性除く樣炕した。

3. 実験の結果 実験の結果を第 5 表、第 6 表、第 1 図〜第 8 図に示す。骨材の各種試験の詳細は「冒材試験

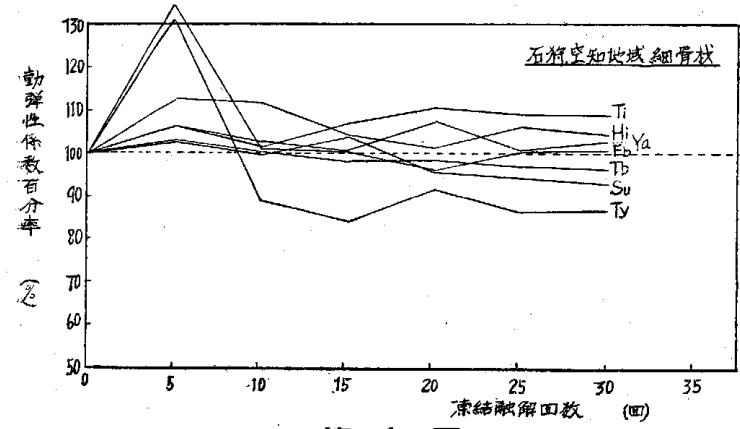

第 1 図

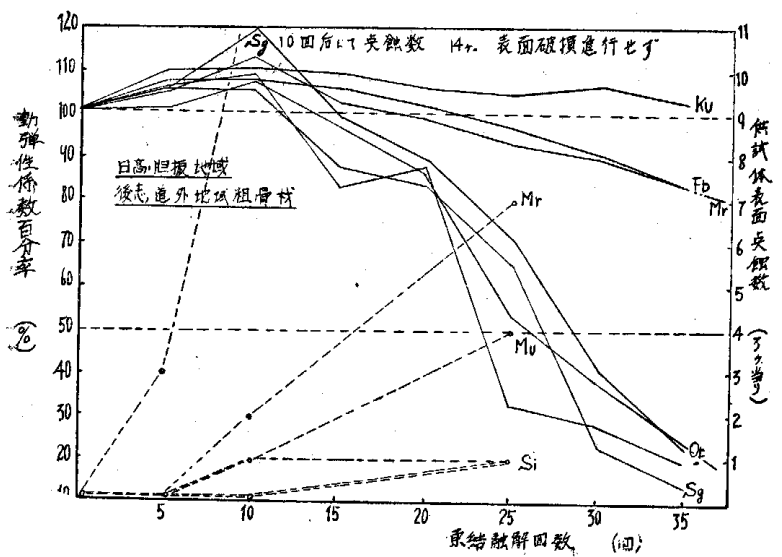

第 2 図

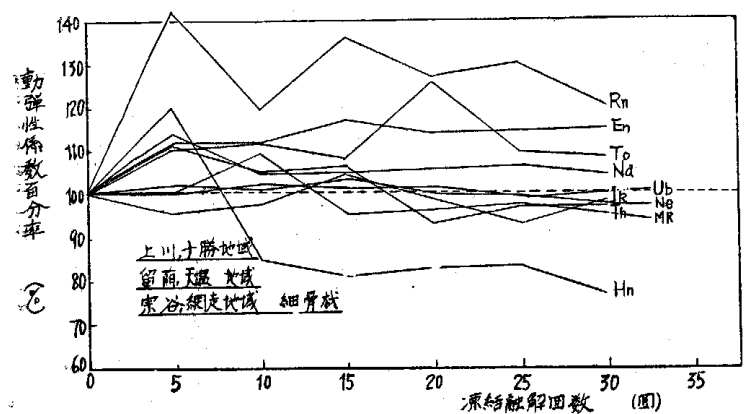

第 3 図

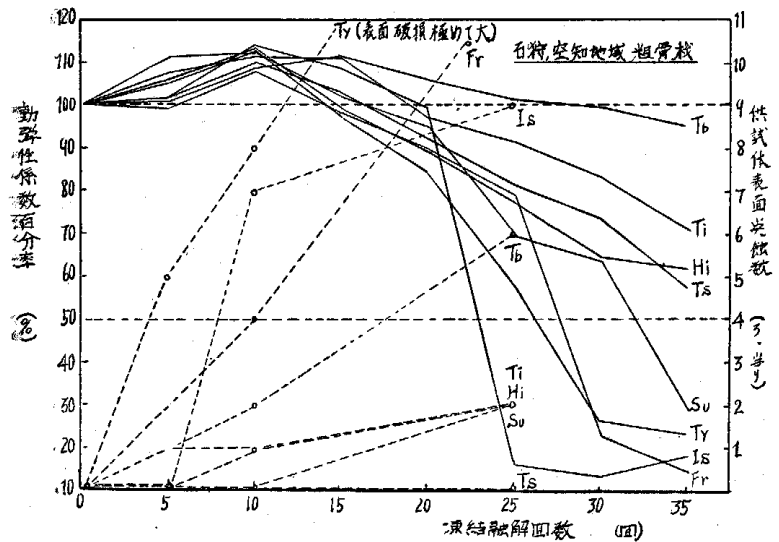

第 4 図
と粗骨材の破砕試験法」* 飞記載。

4. 考 察

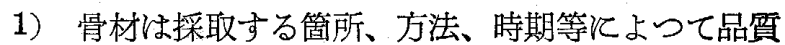
は変動するので、ここに得られた資料は固定的な值では

*文献 $(8)$

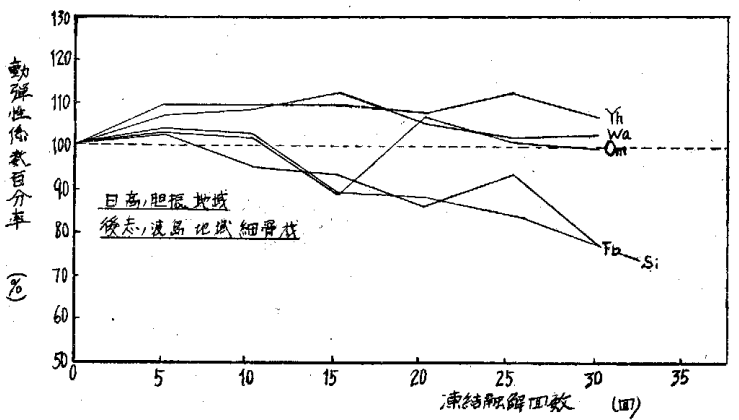

第 5 図

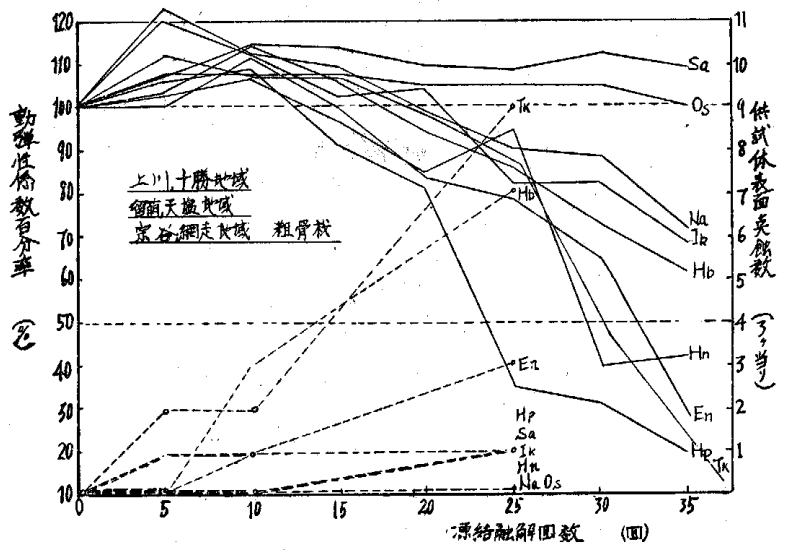

第 6 図

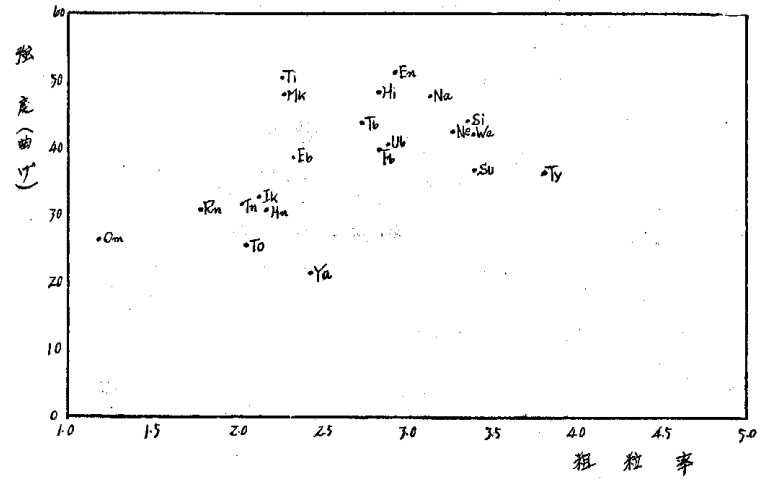

第 7 図

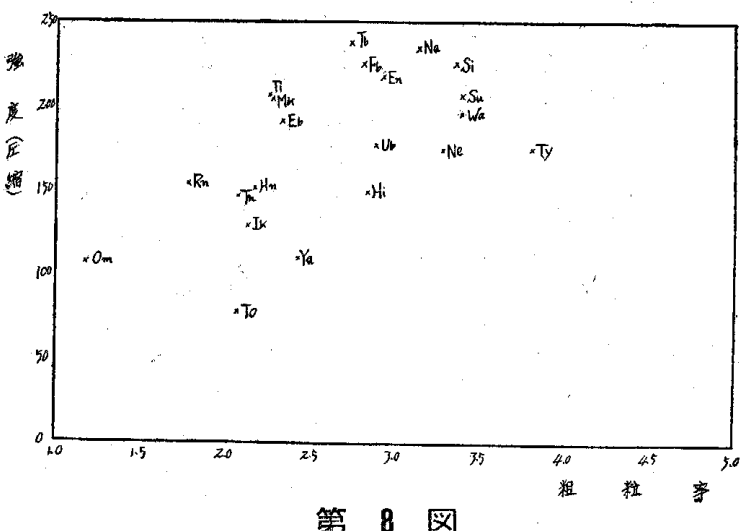


ない。併し骨材選択上の一資料となり得ると考える。

2）細骨材に上る供試体は今回は余り重点を置かなか つたので実験計画も充分とは云壳ない。モルタル強度と 粒度との関係を求めると、第 7 図〜第 8 図に示す如くな り、細骨材の品質判定の資料になる。

3）モルタルの W/C が $65 \%$ の時に此の実験の涷融 回数では、細骨材の良否は差程モルタルの耐凍害性汇影 響は持たない。今回の実験ではセメント使用量が一定で フローを変光た方法であつたが、細骨材の比表面積を考 えると粒度の小さい試料で性不利な条件と考光られるが 差程の開きを見なかつた。

4）コンクリートの倲害に粗骨材は影響をあた学を。 実験結果により水セメント比 $65 \%$ 、セメント使用量 293 $\mathrm{kg} / \mathrm{m}^{3}$ 程度のプレインコンクリートでは明らか飞耐凍害 性に及ぼす粗骨材の影響による差があらわれた。例えば 札内川、当別川、鵡川等住して鮘川、豊平川がその差 を示した如くである。然し今回の報告は各骨材について その耐凍害性の比較資料孝得る事が主眼点であつたた め、コンクリートの調合と粗骨材との関係については今 後信る事とする。

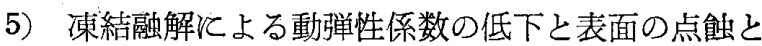

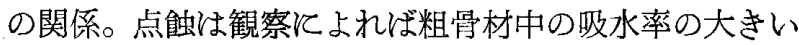
軟石類、きれつを持つ石等による事は明らかであるが、 表面点蝕を生じても動弾性係数快必ずしも低下はしな い。又一方点蝕が全く㸾められなくとも動弾性係数の低 下する粗骨材もある。当別川、䳂川等はきれつを含む石 が多く、招し泊は吸水率の多、多孔質の砂利であるとも かかわらず、動弾性係数比よる結果は良好である。所が 静内産の海砂利は吸水率も少く、破碎試験* 飞子札内川 産のものに近いよい結果を得ていたが、動弾性係数によ る耐凍害性は余りよくない。此の事は粗骨材とモルタル との附着力が凍結融解により害される事が要因になつて いるものと考えられる。又此の他にアルカリ骨材又応に よる影響屾ては疑念が残るがこれは今後の研究に俟 たねばならない。

6）凍結融解試験方法とついての提案。今回の実験で は建築物の凍害を再現する事を目的として比較的に弱い 凍結融解を行つたのであるが動弾性係数が低下しない場 合にる粗骨材による点蝕が進も場合がある。建築物の耐 凍害性について考学るならば動弹性係数の低下はコンタ リート構造物の強度の低下となり、最も重要な事項であ るが、建築物の外観を損い更浮被害を拡大させる点蝕も 考慮する必要がある。点蝕が進むならば表面より钵害が 進行してコンクリートの強度低下る促進する事が考克ら

* 交献 $(8)$
れる。重量損失による而凍害﨡損失の表現法も点蝕によ る凍害を示し得るわけだが、表面の凍害が相当に進まね ば表わし離いから余り適当ではない。そこで建築物に使 用するコンクリートの附凍害性については動弾性係数の 低下と単位表面積あたりの点蝕の数を関連させて判定を 行つていく事を提案したい。点蝕は初期に於て顕著に表 われるから凍結融解の初期に於ける点蝕の数によつて動 弾性係数の低下速度によつて表現される而凍害性を或程 度割引いて考光る事がその一方法と考光られる。具体的 な方法については今後の研究に譲る事とする。

5. 結び 此の研究で産道粗骨材の耐凍害性を比較す る資料が得られた。調合設計に際して耐凍害性を考虑し ないで決定された建築用のプレインコンクリートでは粗 骨材の差に上る凍害の差が大である事も明らかれされ、 点蝕と動弾性係数の低下を带に併用して検する事の重要 性を言めた。

附記 此の実験飞当つては、北海道大学建築工学科助 教授洪悦郎氏の指導により、大塚康二、鈴木雅夫両君の 御助力により、又研究室諸氏の御指導、御助力に上り行 われた事を記して感謝の意を表するものであります。な 特炤和 31 年度交部省科学研究助成補助金及び昭和 32 年度文部省科学試験研究費の一部によつて行われたるの， である。

[参考文献]

(1) F.C. Lang and C.A. Hughes : Accelerated freezing and thawing as a quality test for concrete aggregates, Proc. A.S.T.M. 1931.

(2) C.E. Wuerper and H.K. Cook: Automatic: accelerated freezing and thawing apparatus. for concrete. Proc. A.S.T.M. 1945.

(3) A.S.T.M. Standard : C 292-52 T; Resistance of concrete specimens to slow freezing and thawing in water or brine, Tentative method. of test for.

(4) P.T.F. Wright \& J.M. Gregory : An investigation into method of carrying out accelerated freezing and thawing test on concrete. Mag. of Concrete Research, Vol. 6, Mo. 19, Mar. 1955, p. 39-47.

（5）大坪喜久太郎、前田直方：北海道産骨材の品質 について 北海道大学工学部研究報告第 9 号。

（6）洪悦郎、服部隆、木下栄三：北海道汇於けるコ ンタリート骨材の耐久性 セメント技術年報 IX 1955 。

（7）服部隆：骨材の岩種がコンクリートの耐凍害性 飞及洔す影響 セメント技術年報XI 1955。

（8）服部隆：骨材の試験之粗骨材の破砕試験法（コ: ンクリートの耐久性飞及に゙す骨材の影響第 1 報） 日本建築学会論交報告集第 57 号、昭和 32 年度。 